\title{
FEAR OF THE AGE: NOMOPHOBIA (NO-MOBILE-PHONE)
}

\begin{abstract}
Nowadays, developing technology has brought some addictions into our lives. Smart phone addiction, which is seen with the introduction of smart phones in our lives, has become remarkable in daily life. In the digital age we live, almost every process is handled by smart mobile phones. This makes mobile technologies an indispensable part of our day.

This work is designed to give information about nomophobia, a new concept known as fear of lack of mobile telephony.

As a result of the study, the widespread use of smart phones made it easier for individuals to make their daily lives easier but on the other hand they caused many social and psychological problems.
\end{abstract}

Key words: Nomofobi, Smart Phone, Addiction

\section{INTRODUCTION}

With the rapid development of technology in the age of technology, people's lifestyle has changed. It has become possible for people to meet their needs almost without fatigue. This situation was made possible by the spread of the Internet. In particular, the integration of mobile devices with the Internet has made it possible to access information and services at any time.

With the rapid development of technology, people's lifestyle has changed and many technological devices have become necessary. The latest versions of mobile phones, which are rapidly increasing in number of users, have combined the features of the phone and computer systems and have collected both communication and online status on the same device. These devices were generally called smart phones and soon replaced the classic mobile phones.

Smart phones can be used to check e-mails, take photos or videos, weather, map, bulk shipments or purchases, business or commerce in many other areas (Polat, 2017). Mobile phones and smartphones voice communication, internet connection, camera, navigation, multimedia, calculator, voice recording and so on. While facilitating our lives with services, it causes undesirable effects such as addiction and restlessness (Gördağ, Öztora and Dağdeviren, 2017).

${ }^{1}$ Selcuk University, Faculty of Health Sciences, Department of Health Management. serife_eren.89@ hotmail.com, ORCID ID https://orcid.org/0000-0002-4141-9110 
In this study, the concept of olarak nomophobia telefon and the concept of "deprivation of the smartphone olan is given.

\section{NOMOPHOBİA CONCEPT}

Nomophobia is a new concept that points to excessive and problematic use of mobile technologies in psychological terminology (Gezgin et al., 2017). Nomophobia is a concept close to the problems of addiction, but is among the phobias. Nomophobia is considered to be associated with unwarranted fears and the negative physical and mental states of these fears (Erdem et al., 2016). Nomophobia, defined as the new phobia of the modern age, is defined as the fear experienced when the individual cannot reach the mobile device or communicate on the mobile phone (King et al., 2013; Yildirim and Correia, 2015). Nomophobia is seen as a condition that negatively affects a person when they forget the person's phone, are out of range or when the phone is out of charge (Dixit et al., 2010). Smart phones have internet access, social media applications and many applications can be used, and the ability to communicate quickly makes individuals more busy with smartphones and more concerned when they cannot access these devices (Y1ldırım \& Correia, 2015; Y1ldırım et al., 2016 ).

The term nomofobia was first introduced as a result of a research commissioned by The Post Office in England in 2008. It was concluded that 53\% of respondents felt uneasy when they lost their smartphones, when they ran out of batteries or were out of coverage, $58 \%$ of men and $48 \%$ of women experienced this anxiety (Bahi and Deluliis, 2015). As a result of another survey conducted in the UK in 2012, the rate of smartphone abstinence increased from 53\% to 66\%. Furthermore, contrary to the 2008 study, $70 \%$ of women and $61 \%$ of men were stressed when they could not reach the smart phone (SecurEnvoy, 2012).

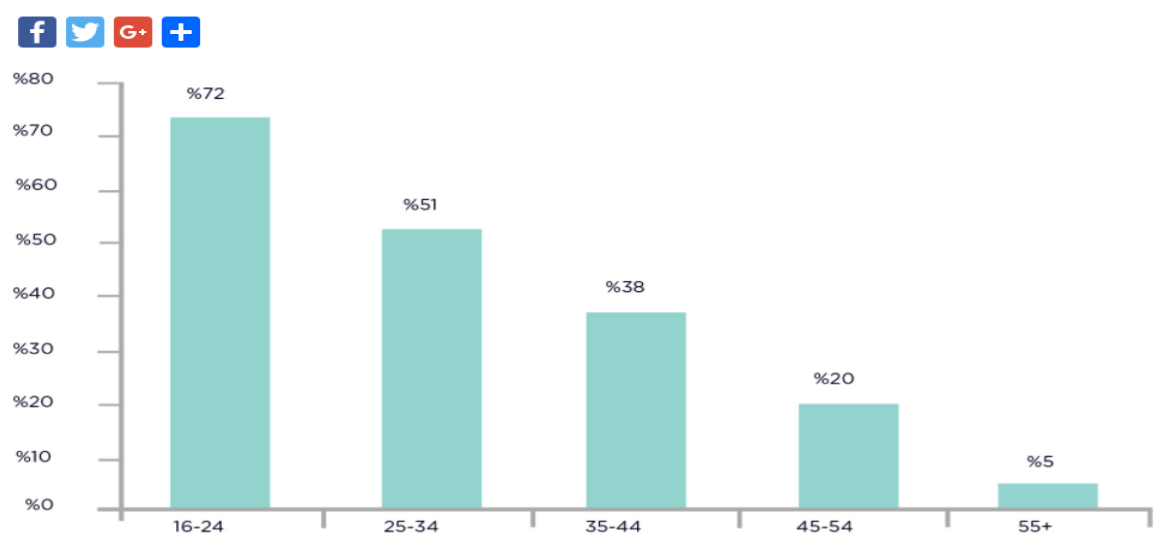

Graph 1. Smart Phone Usage Rates by Age in Turkey (2015)

Source: Google Consumer Barometer

Chart 1 based in Turkey, smartphone use has the highest (72\%) of 16-24 years, while the lowest $(5 \%)$ is available in iron 55 years. In literature, it is seen that there are many nomophobia studies on young individuals (Kaur and Sharma, 2015; Deshpande, 2015; Cheever et al., 2014; Gezgin et al., 2017; Erdem et al., 2016). 
Characteristics of nomophobic individuals; behaviors such as checking for continuous messages or calls, being out of or out of coverage, hearing anxiety and tension, leaving the phone open for 24 hours, entering the bed with a smart phone (Bragazzi and Pente, 2014). In addition, it is stated that in general, there are negative conditions such as neck pain, increased likelihood of accidents, loneliness, depression, decreased physical and social activities in life expectancy, low self-esteem in smart phone addicts which is a close concept with nomophobia (Takao et al., 2009; Tan et al., 2013; Şar, 2013).

The patient is still in the first phase if the nomophobia is distant from smartphones, stress or panic, the perception of surrounding events, the feeling of continuous mobile device control. However, the hormone that gives the person a sense of happiness shows that the dependency phase increases when the person's device becomes secretive (Polat, 2017).

The defined symptoms of nomophobia are as follows (Bragazzi and Pente, 2014):
1. Spend a lot of time with your smartphone
2. To keep the mobile devices' chargers with them continuously,
3. Concern for ideas such as losing smartphone, being out of coverage
4. Frequent calls or checking messages
5. The smartphone does not turn off for 24 hours;
6. Communicating with new technologies by limiting social interaction face to face,
7. Exposure to large costs and debts by using a smartphone is reported.

\section{PROBLEMS CAUSED BY NOMOPHOBIA}

Smart phones, along with the innovations and conveniences brought to daily life, also cause some problems. When used correctly, smart phones that provide benefits and convenience in many areas, cause serious damage when used unconsciously; physical and psychological health problems are beginning to create. These include:

- Health problems such as headache and eye impairment and sleep disturbance due to continuous screen viewing (Kwon et al., 2013),

- Reduction of face-to-face communication due to social media monitoring and message communication, and causing people to become a-socialized (Kwon et al., 2013; Choi et al., 2012),

- Consistency of concentration due to the desire to control the mobile phone (AlKhlaiwi and Meo, 2004),

- Meeting the wrong people through comfortable communication with everyone and causing people to be attracted to unhealthy and illegal environments (Dredge et al., 2014: 13-20).

- Obsessed obsessions with obsessive use and anxiety and may cause addiction (Chiu, 2014), 
- Causes accidents at home, workplace, traffic due to distracting feature (Nasar et al., 2008),

- It is observed that there are various problems such as the ability to intervene in the private life of the people due to spyware and to get their passwords (Ünal, 2015).

\section{CONCLUSION}

Nomophobia appears as a proof of how important technology is in human life. Nomophobia, a digital disease, has become quite widespread and can be seen in almost every individual.

Smart phones facilitate human life on the one hand, while on the other hand many social and psychological problems cause. As a result of people's dependence on mobile devices, nomophobi, when staying away from mobile devices, the person can be seen by the effects such as nervous, stress or aggressive behavior.

In order to talk about nomophobia, there must be many indications, such as the fear of losing the phone, not taking the phone from the bed while sleeping, calling continuously and checking the messages (Bragazzi and Pente, 2014).

In Turkey, smartphone use has seen the highest among 16-24 year olds. Therefore, it is seen that there are many nomophobia studies on young individuals (Kaur and Sharma, 2015; Deshpande, 2015; Cheever et al., 2014; Gezgin et al., 2017; Erdem et al., 2016).

\section{REFERENCES}

Al-Khlaiwi, T. ve Meo, S.A. (2004). Association of Mobile Phone Radiation with Fatigue, Headache, Dizziness, Tension and Sleep Disturbance in Saudi Population. Saudi Medical Journal, 25(6), 732-736.

Bahi, R.R. ve Delulis, D. (2015). Nomophobia, (Ed.) Yan, Z., Encyclopedia of Mobile Phone Behavior 1,2,3, IGI Global, Hershey, PA.

Bragazzi, N.L. ve Pente, G.D. (2014). A Proposal for Including Nomophobia in the New DSM, Psychology Research and Behavior Management, 7, 155-160.

Cheever, N. A., Rosen, L. D., Carrier, L. M., ve Chavez, A. (2014). Out of Sight is not out of Mind: The Impact of Restricting Wireless Mobile Device Use on Anxiety Levels among Low, Moderate and High Users. Computers in Human Behavior, 37, 290-297.

Chiu, S. I. (2014). The Relationship Between Life Stress and Smartphone Addiction on Taiwanese University Student: A Mediation Model of Learning Self-Efficacy and Social SelfEfficacy. Computers in Human Behavior, 34, 49-57.

Choi, H. S., Lee, H. K. \& Ha, J. C. (2012). The Influence of Smartphone Addiction on Mental Health, Campus Life and Personal Relations-Focusing on K University Students. Journal of the Korean Data and Information Science Society, 23(5), 1005-1015.

Deshpande, A. (2015). Mobile Addiction and Associated Factors Amongst Youth. Indian Journal of Mental Health, 2(3), 244-248.

Dixit, S., Shukla, H., Bhagwat, A. K., Bindal, A., Goyal, A., Zaidi, A. K., ve Shrivastava, A. (2010). A Study to Evaluate Mobile Phone Dependence Among Students of a Medical College and Associated Hospital of Central India. Indian Jounal of Community Medicine, 35 (2), 339-341. 
Dredge, R., Gleeson, J., ve Piedad Garcia, X. (2014). Cyberbullying in Social Networking Sites: An Adolescent Victim's Perspective. Computers in Human Behavior, 36, 13 20

Erdem, H., Kalkın, G., Türen, U., ve Deniz, M. (2016). Üniversite Öğrencilerinde Mobil Telefon Yoksunluğu Korkusunun (Nomofobi) Akademik Başarıya Etkisi, Süleyman Demirel Üniversitesi İktisadi ve İdari Bilimler Fakültesi Dergisi, 21(3), 923-936.

Gezgin, D. M., Şumuer, E., Arslan, O., ve Yıldırım, S. (2017). Nomophobia Prevalence among Pre-service Teachers: A case of Trakya University. Trakya Üniversitesi Eğitim Fakültesi Dergisi, 7(1), 86-95.

Google Consumer Barometer, https://www.consumerbarometer.com/en/ erişim tarihi:10.11.2018

Gördağ, Ö.E., Öztora, S., Dağdeviren, H.N. (2017). Birinci Basamak Nomofobiyi Ne Kadar Taniyor? 16. Ulusal aile Hekimliği Kongresi, Ankara.

Güzeller, C.O. ve Coşguner, T. (2012). Development of a Problematic Mobile Phone Use Scale For Turkish Adolescents, Cyberpsychology, Behavior, and Social Networking, 15, 205-211.

Kaur, A., ve Sharma, P. (2015). A Descriptive Study to Assess the Risk of Developing Nomophobia among Students of Selected Nursing Colleges Ludhiana, Punjab. International Journal of Psychiatric Nursing, 1(2), 1-6.

King, A.L.S., Valença, A.M., Silva, A.C.O., Baczynski, T., Carvalho, M.R., ve Nardi, A.E. (2013). Nomophobia: Dependency on Virtual Environments or Social Phobia? Computers in Human Behavior, 29(1), 140-144.

Kwon, M., Lee, J.Y., Won, W.Y., Park JW, Min, JA ve Hahn, C. (2013). Development and Validation of a Smartphone Addiction Scale (SAS). PloS One, 8(2), 5693.

Nasar, J., Hecht, P. ve Wener, R. (2008). Mobile Telephones, Distracted Attention, And Pedestrian Safety. Accident Analysis \& Prevention, 40(1), 69-75.

Polat, R., (2017), Dijital Hastalık Olarak Nomofobi, e-Journal of New Media / Yeni Medya Elektronik Dergisi, 1(2), 164-172.

SecurEnvoy (2012), 66\% of The Population Suffer from Nomophobia The Fear of Being without Their Phone, https://www.securenvoy.com/blog/2012/02/16/66-ofthe-populationsuffer-from-nomophobia- the-fear-of-being-without-their-phone, 09.01.2018

Şar, A.H. (2013). Examination of Loneliness and Mobil Phone Addiction Problem Observed in Teenagers from The Some Variables", International Journal of Social Science, 6(2), 1207-1220.

Takao, M., Takahashi, S. ve Kitamura, M. (2009). Addictive Personality and Problematic Mobile Phone Use, Cyberpsychology and Behavior, 12, 501-507.

Tan, Ç., Pamuk, M. ve Dönder, A. (2013). Loneliness and Mobile Phone, Procedia Social and Behavioral Sciences, 103, 606-611.

Ünal, M.H. (2015). Ankara Yıldırım Beyazıt Üniversitesi Tıp Fakültesi Öğrencilerinin Akıllı Telefon Bağımlılık Düzeylerinin Belirlenmesi, Uzmanlık Tezi, Sağlık Bakanlığı Yıldırım Beyazıt Üniversitesi Tıp Fakültesi Aile Hekimliği Anabilim Dalı, Ankara.

Yıldırım, C., Sumuer, E., Adnan, M., ve Yıldırım, S. (2016). A Growing Fear: Prevalence of Nomophobia Among Turkish College Students. Information Development, 32 (5), 1322-1331.

Y1ldırım, C., ve Correia, A. P. (2015). Exploring the Dimensions of Nomophobia: Development and Validation of a Self-Reported Questionnaire. Computers in Human Behavior, 49, 130-137. 